\title{
Kernos
}

Revue internationale et pluridisciplinaire de religion grecque antique

3 | 1990

Varia

\section{Oracles and Divine Inspiration}

\section{Bernard C. Dietrich}

URL: http://journals.openedition.org/kernos/984

DOI: 10.4000/kernos.984

ISSN: 2034-7871

\section{Publisher}

Centre international d'étude de la religion grecque antique

\section{Printed version}

Date of publication: 1 January 1990

ISSN: 0776-3824

\section{Electronic reference}

Bernard C. Dietrich, « Oracles and Divine Inspiration », Kernos [Online], 3 | 1990, Online since 19 April 2011, connection on 01 May 2019. URL : http://journals.openedition.org/kernos/984; DOI : 10.4000/ kernos.984 


\section{ORACLES AND DIVINE INSPIRATION}

Glaukos, the infant son of king Minos of Knossos and Pasiphae, fell into a pithos filled with honey and drowned. After a long vain search his father found the body but only with the help of divine prophets or Apollo himself. Glaukos was eventually restored to life by the famous seer Polyidos. The popular myth, which provided the plot for two lost tragedies by Sophocles and Euripides ${ }^{1}$, was very old, although the first extant version was recorded as late as Apollodorus ${ }^{2}$. In his Sather Classical Lectures over half a century ago Persson explained the myth as a paradeigm of the annual death and rebirth of nature which he believed to be central to Minoan and Mycenaean cult and reflected in contemporary glyptic art $^{3}$. His thesis may be too global for modern tastes, but his reading of the myth's central theme remains compelling to-day.

The tale's basic elements of death, disappearance and renewal are undeniable 4 , indeed some versions substituted Asclepius for the seer Polyidos as a more fitting agent to restore Glaukos to life. But a curious rider to the myth confirms Polyidos' status as the boy's saviour. It is said that Minos would not release the prophet until he had taught his mantic art to Glaukos. On returning to his home in Corinth, however, or possibly Argos according to some, Polyidos craftily took the gift away again by spitting into the child's mouth. The seer and his trick were later additions to the myth implying the existence of linguistic oracles. They also imply incidentally that the oracles originated from an anthropomorphic god speaking in the first person through a prophetic medium, just like the procedure at Delphi in fact ${ }^{5}$. Polyidos means, "the man who knows much», it is a common, practically generic name for seers whose qualifications consisted in the ability to comprehend and interpret divine will. The same Polyidos, or his namesake, is the geron agathos, the goodly sage in the Iliad who tried to prevent his son

1 NAUCK, Frg. Tr. Gr., II, 216.

2 Bibl., II, 1, 3; 3, 1; cf. HyGIN, Fab., 49; 136; ATHEN., II, 51d; Schol. PIND, Pyth., III, 96.

3 A.W. Persson, The Religion of Greece in Prehistoric Times, Berkeley, 1942, p. 9 sq.

4 J. WIESNER, Olympos, Darmstadt, 1960, p. 238-239.

5 Some $90 \%$ of Delphic responses are in the first person; cf. D.E. AuNE, Oracles, in The Encyclopedia of Religion (M. ELIADE, ed.), New York, 1987, p. 81. 
Euchenor from sailing to Troy ${ }^{6}$. His office is comparable to others in Homer like Calchas, the only professional seer in the poems, and the family of Melampus, represented by Theoclymenus in the Odyssey, who traced their ancestry to Pylian Nestor but as seers and warriors belonged to the epic world of archaic Greece ${ }^{7}$. The Thebaid described Amphiaraus, great-grandson of Melampus, as «both seer and able warrior" 8 .

It is difficult to determine when the prophet became involved in Glaukos' myth, but it is unlikely to have been pre-archaic. The perception of his function is epic, and he had acquired his special skill by divine grace like the poet. Though apparently distinct in Homer, both professions were the same in archaic Greek thought, "Make your prophecy, Muse», said Pindar, "and I shall be your interpreter» 9 . In Hesiod's Theogony both the Muses and the poet have knowledge of "things present, future and past", precisely like Calchas in the Iliad 10 . The blind minstrel Demodocus in the Odyssey was taught either by the Muses, we are told, or by Apollo ${ }^{11}$. Both prophet and poet claimed knowledge of the truth by divine inspiration. This notion becomes a commonplace ${ }^{12}$, and also the fact that both prophet and poet were concerned more with present and past than with the future. In that latter more modern sense of oracle only Teiresias really qualifies as a prophet in Homer, because he describes future events to Odysseus in the Nekyia. But he does so in order to further the plot and accordingly fulfils a

$6 \quad$ Il., XIII, 663-670; cf. E. VERMEULE, Götterkult, Göttingen, 1974, p. 116.

7 Od., XV, 225-231; VERMEULE, op. cit., p. 116; cf. Od., XI, 287-292; schol Il., XIII, $663 ;$ Od., XI, 290, etc.

8 In PINDAR, Ol., VI, 17; cf. VERMEULE, op. cit., p. 116.

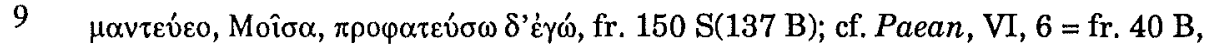

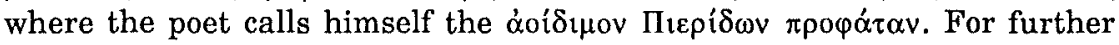
examples and discussions see E.R. DoDDs, The Greeks and the Irrational, Berkeley, 1963, p. 100, n. 118; p. 101 n. 121-122.

10 Hes., Theog., 32; 38 with M. WEST's commentary in Hesiod. Theogony, Oxford, 1966, p. 166.

11 Od., VIII, p. 487-488. The connection between poet and prophet is not made by W. MARG, Homer über die Dichtung, Münster, 1957, p. 10, or by P. MURRAY, Poetic Inspiration in Early Greece, in JHS, 101 (1981), p. 91 n. 25.

12 See H. MAEHLER, Die Auffassung des Dichterberufs im frühen Griechentum, Göttingen, 1963; J. Svenbro, La Parole et le marbre. Aux origines de la poétique grecque, Lund, 1976; B. GENTILI, Poesia e publico nelle Grecia antica, Roma, 1984, p. 203-231, for general discussions of this point, cf. GRAF, Orpheus, p. 101 (cf. infra n. 104). 
practical rather than traditional function in this passage as a kind of poetic device ${ }^{13}$.

So the simple tale of Glaukos encapsulates two quite distinct views of human and divine communication both of which could be described as oracular. The one as old as religion itself concerned with renewal through divine contact, and the other a form of direct communication with the god through the medium of a professional seer and interpreter of divine will. The melting of both illustrates the curious, sometimes haphazard, manner in which religious tradition evolved. The process was continuous and is instructive to anyone enquiring after the origins of Greek oracular practice.

Inspirational prophecy, like poetry, was a product of the archaic period with its fervent desire for oneness with the gods which was also echoed by the telestic ritual of the emerging Bacchic mystery cults. Plato classified all three under the same heading of mania, madness or divine possession, etymologising mantike and manike as identical terms ${ }^{14}$. It was in reaction to this view, which runs counter to the romantic faith in Greek rationalism of the 19th and early 20th century, that Rohde and Nietzsche separated Apolline religion from the ecstatic, irrational and consequently non-Greek cults of the so-called intruder god Dionysus who «forced the Pythia on Delphi»15. Their arguments remain orthodox dogma to this day ${ }^{16}$; but Dionysus was no more or less of an intruder than Apollo, and both gods in one form or another appeared on the Greek scene before the Bronze Age had been rung out. Plato's account reflects aspects of Bacchic maenadism of the 5th century from which perhaps arose the tradition, so joyfully taken up and reinforced by the Christian apologists, of a laurel chewing, drugged and

13 Od., XI, 128-137.

14 Phaedrus, 244-245.

15 DoDDs, Greeks, p. 68.

16 E. ROHDE, $P$ syche, p. 260; 289; e.g. U. VoN WILAMOWITZ-MÖLLENDORFF, Der Glaube der Hellenen, Darmstadt, 1959 ${ }^{3}$, II, p. 30; L.R. FARNELL, Cults of the Greek States, Oxford, 1896-1919, IV, p. 190; K. LATTE, The coming of Pythia, in $H T h R, 33$ (1940), p. 9; M.P. NILSSON, GGR, $\mathrm{I}^{3}$, p. 614, while recognising similarities; W. K. C. GUTHRIE, The Greeks and their Gods, London, 1968, ch. VI-VII; DoDDS, Greeks, p. 69, «The two things are so distinct that the one seems most unlikely to be derived from the other"; more recently J. FONTENROSE, The Delphic Oracle, Berkeley, 1978, p. 207, still argues along the same lines. See also W. BURKERT, Greek Religion (Engl. transl.), Oxford, 1985, p. 224-225, who emphasizes the polar strücture of Greek religion which is symbolized by the two gods, and he traces the conflict between them to Aeschylus. 
raving Pythia at Delphi. The image has been shown up as false ${ }^{17}$ : the Pythia, when inspired by Apollo, was no more frenzied than seer or poet in Homer, or for that matter Cassandra herself who had not yet developed her supernaturel gift or special relationship with Apollo 18 . Oracular and poetic frenzy was a post-archaic, late classical, phenomenon and not the same as the earlier concepts of inspiration ${ }^{19}$. Neither had a place in Homer, least of all in the sphere of Apollo. Epic oracular activity more directly operated through Zeus and his oldest oracle at Dodona ${ }^{20}$, while Apollo acted as a kind of intermediary, the «vicar on earth of the heavenly father» making known to man the will of Zeus ${ }^{21}$. In this epic context Delphi plays a less than minor role. Pytho is mentioned four times in Homer and in only one late passage, which may have been borrowed from Cyclic epic, specifically refers to an oracle there ${ }^{22}$.

Apollo in Homer does not inspire the seer but grants him his skill or knowledge, as in the case of Calchas $(I l, I, 72)$ and Melampus together with his descendants (Od., XV, 252 : Polypheides). But this knowledge is far from specialised : ideally it can be acquired by any hero in epic who may act as his own seer. So Telemachus says to his mother, "I see all these things in my heart and know them, the good and bad alike» (Od., XVIII, 228-229). The hero relies on intelligent conjecture, experience and a measure of intuition for the knowledge in his thymos. Anyone can know the past, according to the proverb and Menelaos in the Iliad $^{23}$, but even Calchas' professional skill of knowing present and future (Il., II, 72) can easily be matched by the wise layman Halitherses who

17 Fon'tenrose, Delphic Oracle, p. 211.

18 VERMEULE, op. cit., p. 115.

19 MURRAY, in JHS, 101 (1981), p. 87, with full modern bibliography. MURRAY, distinguishes between poetic technique and divine inspiration, enthusiasmos, p. 99-100.

20 Il., XVI, 235; Od., XIV, 327-328 = XIX, 296-297. On the age of the oracle at Dodona see H.W. PARKE, The Oracles of Zeus, Cambridge, Mass., 1967, p. 1163; L. TReadwell, Dodona : an oracle of Zeus, Diss. Western Michigan University, 1970; S. DAKARIs, Das Taubenorakel von Dodona und das Totenorakel bei Ephyra, 1963 (Antike Kunst, Beiheft 1); BURKERT, Gr. Rel., p. 114.

21 The phrase is by DodDs, Greeks, p. 75, who cites AEsch., Eum., 616 sq., cf. FlACELIĖRE, Greek Oracles, p. 28; W.H. PARKE, Greek Oracles, London, 1967, p. 39.

22 Od., VIII, 79-80. The other exs. are Il., II, 519; IX, 404-405; Od., XI, 580-581.

23 Il., XVII, 32 = Il., XX, 198; cf. HESIOD, W\&D, 218; PLATO, Symp., 222b. 
counselled the slain suitors' kin in the Odyssey ${ }^{24}$. There is no Pythia in Homer, frenzied or sober, no ecstatic Cassandra possessed and inspired by Apollo, in short no unambiguous trace of "Inspirationsmantik» 25 . Theoclymenus' lurid prediction of the suitors' imminent fate is no exception, nor a "Vorform» of intuitive mantic ${ }^{26}$, but a reasonable deduction that the gods will punish them for their sins, for, as he says, «I have eyes and ears and an understanding mind" (Od., XX, 365-336). Again, Helenus comprehending the intention of Athena and Apollo to call a pause in the fighting and arrange a duel in Book VII is poetic invention like Teiresias' advice in the Nekyia ${ }^{27}$.

Most, if not all, such apparent bordeline cases can be resolved along similar lines showing that prophecy in Homer is inductive, that is from physical signs, and that all other forms may be explained as poetical device. Both Calchas and Helenus interpret the gods' will by signs, in fact, they are "the best of augurs" 28 . The poet skilfully embroidered this primary function with a more intuitive, or divinely inspired, motivation of the hero in order to suggest the closeness of Olympian and human levels in Homer. Thus not only the seer but all can understand the thought and purpose of the Olympians, but occasionally the impression creeps in of a mortal «prophesying» directly with the voice of a god. So Helen interprets an omen at the departure of Telemachus from Sparta. At a critical moment an eagle carrying a goose in its claws flew by on the right. The meaning of the portent is obvious, it fills with joy the hearts of all those present. But Helen's response suggests deeper powers of perception, «I will prophesy», she says, «what the gods have cast in my mind and how I think it will come to pass» (Od., XV, 172-8). The passage parallels $I l$., VII, yet Helen, too, simply reads the signs and the rest is poetic colouring without religious substance ${ }^{29}$.

24 Od., XXIV, 452. The adjective of refers to this context only, i. e. the company of enraged Ithacans.

25 Already seen by A. BouChé-LECLERCQ, Histoire de la Divination dans l'Antiquité, Paris, 1879 (repr. 1963), II, p. 141; cf. NLsSON, GGR, $\mathrm{I}^{3}$, p. 166; 547; DoDDS, Greeks, p. 70. For a different view see R. FLACELIÈRE, Greek Oracles (Engl, transl.), London, 1965, p. 20, who cites $I l$., VII, p. 44-45 as an example of divine inspiration, but see n. 24.

26 C. ZINTZEN, Mantik, in Kleine Pauly, III (1979), p. 970.

27 Il., VII, 44-45. «Not by the outer ear, but by his power as soothsayer", LEAF, conveys the main idea.

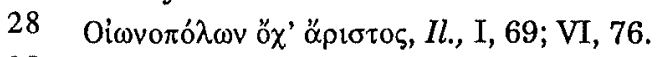

29 Above n. 27, 
Sometimes in Homer the practical and imaginative are skilfully interwoven. So Penelope dreams of an eagle killing her twenty favourite geese (Od., XIX, 537-550); but she is not relating a dream oracle despite her ensuing colourful account of true and false dreams (562-567). What she actually saw was the normal omen which may be interpreted by the professional augur or, as in this case, by any intelligent witness ${ }^{30}$. Such omens were physical signs, like the flight of birds - ornis means both birds and omen in Homer -, the configuration of the liver and entrails of sacrificial victims or indeed any phenomenon by which the gods, that is mostly Zeus, made their will manifest. The variety of these signs in epic is considerable, including lightning, sudden sounds, a rainbow or falling star like Athena descending, and wondrous portents, usually of war in epic poetry, but they are always directly visible 31 .

It is important then to distinguish between the machinery of prophecy and epic divine parousia. The one is not related to the other, indeed the close physical proximity of gods to men in Homer turns out to be epic literary convention rather than the survival of prehistoric Aegean religious beliefs. On the face of it divine epiphany in Homer seems reminiscent of earlier religious practice. Matz and Nilsson have enshrined epiphany as the central factor of Minoan and Mycenaean religion on the strength of the surviving iconography ${ }^{32}$. It has in fact recently been argued from the art and architecture of the New Palace period that two distinct types of epiphany obtained in Minoan cult : one ecstatic, i.e. the vision by worshippers of an anthropomorphic divinity, and the other consisting in ritually enacted epiphanies in special areas of the palace ${ }^{33}$. The evidence for invocatory titles of Minoan and Mycenaean deities further enhances the impression of constant divine

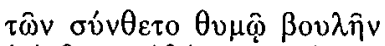

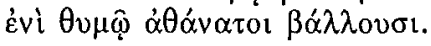

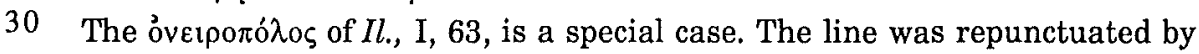
ARISTARCHUS and athetized by ZENODOTUS, see LEAF and KIRK, ad. loc. The sentiment is Homeric invention, hence, too, the explanatory clause about dreams being from Zeus. In popular belief a daimon can send good and bad dreams which may of course be compared with oracles, see DIETRICH, Death, Fate and the Gods, repr. London, 1967, p. 316.

31 For a list of examples in Homer with refs to the relevant modern literature, see VERMEULE, Götterkult, p. 118-120.

32 M.P. NILsson, $M M R^{2}$, 1950; F. MATZ, Göttererscheinung und Kultbild im minoischen Kreta, Wiesbaden, 1958.

33 R. HÄGG, Epiphany in Minoan Ritual, Mycenaean Seminar, 17 November 1982 , in BICS, 30 (1983), p. 184-185. 
proximity and the expectation of their physical presence at religious ceremonies ${ }^{34}$. The concept of intuitive, divinely inspired prophecy seems closely related suggesting perhaps that a few incidents like Penelope's dream in $\mathrm{Od}_{\text {., }} \mathrm{XIX}^{35}$, or indeed certain objects such as Teiresias' golden staff $^{36}$, were direct survivals from the prehellenic past.

But the case for Minoan/Mycenaean inspirational oracles has not been made out, and the link between epiphany, whatever from that took, and intuitive prophecy remains an assumption without base in archaeology or literature. Certainly it is not supported by anything said in Homer : either the epic poets ignored an earlier Minoan/Mycenaean tradition or there was none to observe. There is a need to reconsider the evidence for Bronze Age origins of historical Greek oracles. That of Zeus at Dodona enjoyed a reputation of great antiquity; yet there is no reliable indication that it had first belonged to a Mediterranean earth goddess prophesying there from her cave ${ }^{37}$. At Pytho, too, the tradition of the baetylic omphalos alone is not enough to prove the existence of a prehistoric oracle there ${ }^{38}$. It seems even more far fetched to describe the Pythian Apollo as "the hypostasis of the Great Minoan God in his mantic capacity» 39 . But the Greeks themselves from classical times created spurious links with the past because they wished to validate Delphi's ageless importance. Hence the oracle's legendary foundation myths and responses, including the prescription of an annual tribute to king Minos of Knossos by the city of Athens. The latter story occurs in Ovid, Hyginus, and still in Pausanias without reference to Delphi ${ }^{40}$, and it

34 DIETRICH, Origins of Greek Religion, Berlin, 1974, p. 157-167; 180; 189; 236; $239 ; 285-286$.

35 DoDDs, Greeks, p. 110.

36. Vermeule, Götterkult, p. 117; H.W. Parke, also explains the prophet Branchus' magic staff as prehellenic, The Oracles of Apollo in Asia Minor, London, 1985, p. 212.

37 H.W. PARKE, The Oracles of Zeus, Oxford, 1967, p. 253.

38 C. Sounvinou-INwood, Myth as History : the previous owners of the Delphic Oracle, in Interpretations of Greek Mythology (J. BREMMER ed.), London, 1987, p. 225.

39 Doro Levi, Gleanings from Crete, in AJA, 49 (1945), p. 304; Features and Continuity of Cretan Peak Cults, in Temples and High Places in Biblical Times (A. BIRAN ed.), Jerusalem, 1981, p. 40 (first in $P P, 33$ [1978], p. 294-313).

40 OvID, Met., VII, 456-460; Paus., I, 27, 10; HygIN, Fab., 41. 
did not in fact predate Oenomaeus' collection of oracles ${ }^{41}$. There is no archaeological evidence for fixed Minoan/Mycenaean oracle sites. Pasiphae's sanctuary at Thalamae with its incubation oracle was an archaic institution 42 .

Other sources are not particularly compelling either, including Linear B, although it is tempting to search for some sort of indication in the vocabulary of the tablets. opetereu/opetoreu, for example, which appears on three Pylian documents, has been interpreted as the title of an official "who sees into the future», «a prophet» ${ }^{43}$, wetereu as «he who sees in the flesh", "a diviner" 44 , and keretao, which occurs once in the Pylian documents ${ }^{45}$, as the genitive of a word meaning whe who gives oracles» 46 . The arguments have been accepted by some ${ }^{47}$, despite linguistic problems ${ }^{48}$. But they are based, one suspects, on preconceived notions of prehistoric oracular activity. In other words, classical procedure has been projected back on to an unknown Bronze Age context without any real corroborative support from other sources. The classical $\chi \rho \eta \sigma \tau$ ń $\theta \varepsilon \hat{\omega}$, whose pronouncements become ineluctable law, hence the impersonal form $\chi \rho \hat{\eta}$ meaning «necessity». The term describes a specialised concept of oracles which can not be paralleled from the Bronze Age.

41 H.W. PARKe-D.E.W. WoRmell, The Delphic Oracle, Oxford, 1956, I, p. 297; J. FontEnrose, The Delphic Oracle, Berkeley, 1978, p. 373-373; Response L45 $=\mathrm{PW} 210$.

42 PAUs., II, 26, 1; Dietrich, Reflections on the Origins of Oracular Apollo, in BICS, 25 (1978), p. 4.

43 PY Ea 805; Eb 294. 1; Ep 704. 1; M. VENTRIS-J. CHADWICK, Documents in Mycenaean Greek, Cambridge, $1973^{2}$, p. 256; 565; M. GÉRARD-RoussEAU, Les Mentions Religieuses dans les Tablettes Mycéniennes, Rome, 1968, p. 153-154, 260. See also BICS, 25 (1978), p. 4-5.

44 PY En 74. 16; Eo 247. 7; En 659. 4 = Eo 444. 3; Ep 539. 13 (together with ijereu /iereu, «priest»); Eb 472; 477; Ed 317; GÉrard-Rousseau, Mentions, p. $154,260$.

45 PY Cn 1287.6.

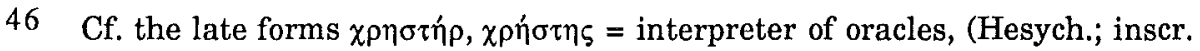

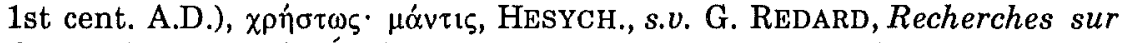
CHRE, CHRESTHAI. Étude Sémantique, Paris, 1953, p. 104, 109.

47 P. LÉvÊQUE, Creto-Mycéniens, in Les Syncrétismes dans les Religions de l'Antiquité (F. DUNAND-P. LÉVÊQUE eds), Leiden, 1975, 34; BICS, 25 (1978), p. 4.

48 See the reviews of GÉRARD-RouSSEAU, by F. BADER, in $R E A, 71$ (1969), p. 135 and C. MILANI, in Aevum, 44 (1970), p. 192-193. 
A better case can be made out for gerasija/gerasijo in Linear B which, if it has been deciphered correctly, links up with Homer and indeed with what is archaelogically shown to habe been common oracular practice in prehistoric times. The word occurs on the eleven Knossian tablets of the $F p$ - series bearing the ideogram for olive-oil. These so-called Olive Oil Tablets probably formed part of a ritual calendar with the record of offerings of oil at different places for deities and priests and under the heading of various months ${ }^{49}$. qerasija obviously described an eminent official who received a disproportionately large amount of oil ${ }^{50}$, the equivalent of Diktaen Zeus and double the ration set aside for Erinys, but in his case probably for ritual purposes. The title has been translated by "augur", on analogy with the Homeric teras meaning "portent" in the form of a «meteorological phenomenon", or any other miraculous $\operatorname{sign}^{51}$. Possibly Teiresias owed his name to the same root ${ }^{52}$, that is difficult to decide, but certainly the equation between Mycenaean and Greek forms can stand on linguistic grounds, if not without some difficulties of its own ${ }^{53}$. Nevertheless this etymology has the merit of reflecting standard Homeric oracular procedure which more obviously than any form of "Inspirationsmantik" echoed prehistoric methods of ascertaining divine purpose in everyday affairs.

Divination and the priestly office of seer have been attested in Mesopotamia from very early times. Babylonia and Assyria practised many forms of oracle by the second millennium B.C., but in the main they depended on the observation of visible signs, that is predominantly mechanical devices like the flight of birds, abnormal human and animal births, the entrails and liver of sacrificial animals, various

49 VENTRIS-ChADWICK, Docs, p. 303-308; L.R. PALMER, The Interpretation of Mycenaean Greek Texts, repr. Oxford, 1969, p. 235-236, doubts their ritual nature but calls them "store-room dockets".

50 121. on $\mathrm{Fp}$.

51 Above n. 31; A. FURUMARK, Ägäische Texte in griechischer Sprache, in Eranos, 51 (1954), p. 103-120; 52, p. 18-60; VenTRIS-CHADwICK, Docs, p. 303.

52 Cf. Etrusc. Terasiaś, Terasials, Schulze, Quaest. Ep., p. 176; originally a chthonic oracle god, according to ROBERT, Oidipus, p. 69, both cited by VENTRIS-CHADWICK, Docs, p. 303-304.

53 PALMER, suggests Therasia, "The Huntress», or a toponym, Interpret. 236. See also J. CHADWICK, The Olive Oil Tablets of Knossos, in Proc. Cambridge Colloquium on Mycenaean Studies (L.R. PALMER \& J. CHADwick eds), Cambridge, 1966, p. 28; 30 who proposes a connection with $\theta$ ń $\rho$, but without enthusiasm. 
forms of lecanomancy, and so ${ }^{54}$. The same means were familiar to the Homeric poets, of course, but they were also known to the Mycenaeans who in fact only left evidence of this kind of purely practical oracular activity between the 14th and 12th century B.C.

They adopted the forms of prophecy of their oriental neighbours in areas of close physical contact. Thirty-two clay models of the liver have been found in Mari with oracular formulae concerning the fate of the rulers of Akkad 55 . They predate the Hammurabi dynasty, but they served the same purpose as an inscribed bronze votive liver from the Mycenaean Temple II at Kition in Cyprus of the 12th century B.C. 56 Other examples of similar ritual livers have turned up in the House of the Hurrian Priest on the slope of the acropolis of Ras Shamra together with Ugaritic mythological texts and Mycenaean rhyta of the 14th/13th century ${ }^{57}$. The city was a famous Mycenaean station at the time, and the archaeological remains point to forms of divination which had obtained in the east since history began, and which continued as the mainstay of epic augurs who in turn must have reflected the practices of the Aegean Bronze Age. However, no clear signs survive of concurrent intuitive inspirational prophecy in Minoan/Mycenaean culture.

The Glaukos myth confused mediumistic prophecy with rebirth and renewal. The expectation of the periodic renewal of life was fundamental to Minoan and Mycenaean religious thought : it evidently formed the point of contact between the Bronze Age and historic "Inspirationsmantik» leaving a remarkably deep imprint on the myth associated with the latter and on every aspect of oracular procedure. The indicators of the enduring tradition are furnished by three symbols in particular : the bee, tripod and the cave. In different combinations these appear in oracular legend and performance so consistently, as to convey the impression of an unbroken tradition stretching back to the prehistoric Aegean. All three have been discussed elsewhere, so that the evidence need not be rehearsed again in detail ${ }^{58}$. Bee, like butterfly,

54 Éd. DHorme, Les Religions de Babylonie et d'Assyrie, Paris, 1949 (Mana), p. 272; p. 275-279 with bibliography.

55 DHORME, Relig., p. 272

56 Y. LYNN Holmes, in The Archaeology of Cyprus, Recent Developments, p. 90120; V. Karageorghis, Cyprus. From the Stone Age to the Romans, London, 1982, p. 104.

57 J.-C. Courtois, Enkomi und Ras Schamra, zwei Aussenposte der mykenischen Kultur, in Ägäische Bronzezeit (H.-G. BUCHHOLZ ed.), Darmstadt, 1987, p. 205.

58 BICS, 25 (1978), p. 5-7. 
with its peculiarly distinctive life-cycle symbolised the expectation of renewal since time immemorial ${ }^{59}$. The Nymphs at Delphi ate honey before uttering their prophecies ${ }^{60}$. The Pythia herself was called melissa by Pindar ${ }^{61}$, and of course our Glaukos drowned in a jar of honey : in his case the symbol of his eventual return also became the instrument of his death 62 .

The tripod cauldron was the standard implement for the ritual of renewal through fire and boiling. Arkas and Pelops were "renewed» in this manner, and Medea's skill at performing a similar service is well known. At Delphi it stood in the adyton of the temple ${ }^{63}$, and the Pythia sat on it during the oracular session. Quite possibly the awkward perch was intended to suggest her own periodic renewal ${ }^{64}$, as some modern scholars claim, but certainly the principal message is never in any doubt.

It equally accounts for the partnership of Apollo and Dionysus at Delphi and their complex one, three and eight year festal cycles. That is a rather more likely reason for their association than any political move by the priesthood to bring Dionysus to Delphi in the 6th century65. His tenure there extended over the winter months during Apollo's absence in the far north. In art and literature, beginning with the Eumenides of Aeschylus, the emphasis is on his affinity with nature, with caves, the Corycian Cave in particular, and with the Nymphs66. The god's seasonal aspect as Divine Child also comes across much more strongly

59 This point was treated most recently by R. LAFFINEUR, in L'iconographie Minoenne (P. DARCQUE-J.-C. Poursat eds), Paris, 1985 (BCH Suppl. XI), p. 252-257; cf. my paper A Minoan Symbol of Renewal, in Journal of Prehistoric Religion, 2 (1988), p. 12-14.

60 Hom. Hym. Hermes, 559.

61 Pyth., IV, 60; cf. Ol., VI, 47.

62 APOLLOD., Bibl., III, 3; 3, 1.

63 PAUS., X, 24, 5; HDT., VII, 141; EUR., IT, 1256; PLUT., De def. or., 437c.

64 Through symbolic boiling, M. WEST, The Orphic Poems, Oxford, 1983, p. 147. BURKERT explains the ritual cooking or roasting of the sacrificial meat as a symbolical renewal, too, Homo Necans, English transl., Los Angeles, 1983, p. 125.

65 To make god and cult respectable, E. RoHDE, Psyche, repr. Darmstadt, 1961, II, p. 54-55; H. JeanmaIRe, Dionysos. Histoire du culte de Bacchus, Paris, 1951, p. 187-191; M. P. NILSSON, GGR, $\mathrm{I}^{3}$, p. 614.

66 AESCH., Eum., 22; 24; cf. SOPH., Ant., 1126; EUR., Ion, 550-553; 714-718; 1125; IT, 1243; Phoen., 226 \& schol. Bacch., 306-309. On Dionysus' affinity to caves in myth and tradition, see P. BoYANCÉ, L'Antre dans les Mystères de Dionysos, in $R P A A, 33$ (1960/61), p. 107-127. 
at Delphi than any sophisticated Nietzschean notion of polarity between the two gods ${ }^{67}$. In Orphic legend the Titans tore the young god apart, boiled his limbs and buried them beside the tripod. Dionysus' tomb there is mentioned by Philochorus and Callimachus ${ }^{68}$, his rebirth by Philodemus ${ }^{69}$. The Orphic account is reflected in similar stories told by Callimachus and Euphorion proving that it was a part of a well known tradition with wider currency than Orphic myth ${ }^{70}$. The child's dismemberment may well be what Plutarch describes as the «unspeakable sacrifice», which the Hosioi performed in the shrine, and part of a ceremonial complex culminating in the Thyiades "waking» Dionysus again in the liknon or winnowing basket ${ }^{71}$.

Apollo's regular disappearance and return were equally seasonal : he shared that characteristic with his divine partner ${ }^{72}$. Originally the Pythia dispensed oracles only once a year, namely in spring on the 7th day of Bysios, when the god returned to his sanctuary and was "renewed» 73 . The important rôle of the cave reinforced the signal : in Delphi it remained an essential element in the literary convention until Roman times ${ }^{74}$, and elsewhere a cave also featured at many other Apolline oracles including Klaros in Asia Minor ${ }^{75}$. However, the particular message contained in this religious assemblage of cave, bee and tripod seems wholly uncharacteristic of Apollo's primary nature : he was no «Jahresgott» 76 or deity of vegetation. The connection surely lies in the specialised form of inspirational oracles. Not only Delphi, but all his oracles were of that type 77 , and evidently it was as the god of

67 See above p. 3 and n. 15 \& 16; BURKERT, Homo Necans, p. 124; Greek Religion, p. 224-225a.

68 Philochorus, 328 F 7 J.; Callim, fr. 517/643; PluT., Is. Os., 365a.

69 PHILOD., De piet., 16g; cf. EUPHOR., fr. 36.

70 CALLIM, fr. 517/643; EuPHOR., fr. 13P,

71 PLUT., Is. Os., 365a; cf. De def. or., 438b; Quaest. graec., 292d; BURKERT, HN, p. 124-125. The waking ceremony perhaps occurred at the start of Dionysus' tenure in the month of Daidaphorios (Nov/Dec), West, Orph. Poems, p. 150; but see NILSSON, GGR, $\mathrm{I}^{3}$, p. $580 \&$ n. 2.

72 Cf. M. WEST, Orph. Poems, p. 150.

73 CAllisthenes (124 F 49 J.), in Plut., Quaest graec., 292c-f; cf. W. BURKeRT, Homo Necans, p. 125.

74 H.W. PARKE, Castalia, in BCH, 102 (1978), p. 213.

75 See BICS, 25 (1978), p. 5-6; on the cave at Klaros, see H.W. PARKE, The Oracles of Apollo in Asia Minor, London, 1987, p. 112-178.

76 But see J. WIESNER, Olympos, Darmstadt, 1960, p. 107, 213.

77 FonTenrose, Delphic Oracle, p. 228. 
inspirational oracles that Apollo took over the trappings of the ancient chthonic rites of renewal through divine communication. Hence the desperate efforts of myth to establish a link between Apollo and nature spirits like the Nymphs, who taught the art of prophecy ${ }^{78}, \mathrm{Pan}^{79}$, and the Muses. The latter were associated with Apollo only at Delphi, where in the time of Simonides they enjoyed a cult near the sanctuary of the Earth goddess ${ }^{80}$. They functioned as nature spirits, too, but their closest links with Apollo were forged from different metal ${ }^{81}$. Plutarch neatly combines all three aspects of poetry, music and mantic skill by ascribing to the Muses the introduction of verse in the oracular responses ${ }^{82}$.

Chthonic oracles were of a different kind 83 , but in form they profoundly affected Delphi giving rise to the tradition of a chasm or cavern in the temple's adyton to which the Pythia and consultants were said to descend for an oracular session. The technical vocabulary for this procedure includes the verbs katabainein, katerchesthai and katienai ${ }^{84}$, although archaelogists have searched in vain for subterranean structures in the sacred precinct 85 . Attention briefly focussed on the Corycian Cave, some seven miles distant, as the presumptive first seat of the oracle. But cult there began relatively late and not before the 7 th century B.C. ${ }^{86}$ in response to the tradition rather than as its founder, because the cave moved into prominence only during the centuries of the oracle's greatest influence. At Klaros, which looked to Delphi for its origins, the identical tradition took hold and the cave remained central to the consultation of its oracle, from the 7 th

78 Thriae, Hom. Hymn Hermes, 551-561, and Append III in SiKeS \& ALLEN'S commentary.

79 APOLL., I, 4, 1.

80 Fr. 72a Page.

81 Below p. 171. H.W. PARKE, Apollo and the Muses, or prophecy in Greek verse, in Hermathena, 130/1 (1981), p. 99-112, who believes that the cult of the Muses at Delphi antedated Apollo's arrival, p. 105.

82 PLUT., 402c.

83 Above p. 159. This point does not emerge clearly from my earlier discussion in BICS, 25 (1978), p. 5.

84 PluT., Moral., 397a; 407d; 408c; 438b; Timol., 8, 2; FonTEnRose, Delph. Or., p. 227.

85 See Fontenrose's decisive treatment in ch. VII of Delphic Oracle, p. 196-232.

86 BICS, 25 (1978), p. 5 \& n. 94 for ref.; see also my review of FonTENRose, Delph. Or., in AJPh, 101 (1980), p. 234-241. 
century B.C. at least until the time of Tacitus ${ }^{87}$. But chthonic signposts like chasm and spring became features of many Apolline oracles from Ionian Didyma to the Boetian oracles of Apollo Ptoios, Tegyraios, Thyraios and others that developed in archaic times ${ }^{88}$. They were therefore relatively late implants on the oracular tradition and not Apolline or really part of mantic procedure at all.

Nevertheless Delphi's oracular history became contaminated with the myth of earlier tenancies by Ge and her daughter Themis, of an intrusive Apollo violently wresting control from the primordial earthpowers ${ }^{89}$. In other versions the transfer occurred more peacefully ${ }^{90}$, but generally with an underlying sense of succession from the chaotic old to a new order ${ }^{91}$. However, the case for previous owners at Delphi is weak at best : the oldest accounts agree on Apollo as first comer and tenant ${ }^{92}$, while votives in the sanctuary area and the earliest peribolos wall indicate a foundation date not before the 8th century B.C. The oracle, if oracle there was from the beginning, must have been in the open until the construction of the first temple over a century later ${ }^{93}$. It had always functioned by direct divine inspiration : arguments for other and older forms of prophecy in the sanctuary, including the much debated lot oracle, generally depend on the same misleading blend of traditions ${ }^{94}$.

87 TAC., Ann., II, 54; PARKE, Or. of Apoll., p. 112-178, on Klaros.

88 A. SCHACHTER, A Beotian Cult Type, in BICS, 14 (1967), p. 1-16.

89 EUR., IT, 1239-1282; PINDAR, fr. 55; cf. FlACELIERE, Gr. Oracles, p. 34. In EUR., Orestes, 163-165, Apollo gave his command to Orestes from Themis' tripod at Delphi.

90 AEsCH., Eum., 1-8; cf. APOLloD., I, 4, 1; PluT., De def. or., 421; PAUs., X, 5, 6, with Poseidon as a fourth element.

91 C. SOURVINOU-INWOOD, art. cit., p. 226-227.

92 Hom. Hymn Apollo, 182-183; 388-390; 438-451; 514-519; ALCAEUs, fr. 142 Page in HIMER., Or., 48, 10-11; cf. SoURVINOU-INwOoD, art. cit., p. 215-241.

93 P. De La Coste-Messelière, Topographie Delphique, in BCH, 93 (1969), p. 731-732; 737 .

94 The argument hinges on the meaning of $\alpha$ 'vaıєiv, P. AMANDRY, La mantique apollinienne à Delphes : Essai sur le fonctionnement de l'oracle, Paris, 1950, p. 29-36; 84-85; 232-233, who argues for two kinds of oracle at Delphi; cf. an earlier simpler view by F.E. RoBBINs, The Lot Oracle at Delphi, in $C P h, 11$ (1916), p. 278-292; PaRKe, Delphic Oracle, I, p. 18-19; H.-V. HeRrmanN, Zur ältesten Geschichte von Olympia, in MDAI(A), 77 (1962), p. 11 : inspirational mantic only later replaced earlier methods; C.R. WHITTAKer, The Delphic Oracle : Belief and Behaviour in Ancient Greece and Africa, in HThR, 58 (1965), p. 27-28; NILSSON, GGR, I³ , p. 167, 171; BURKERT, Gr. Rel., p. 116. The question appears to have been settled by FONTENROSE, Delph. Or., p. 219-223. 
Prophecy was an acquired skill for Apollo : he did not bring it with him from the east when he first arrived in Cyprus, Mycenaean Greece and in Crete before the end of the Bronze Age ${ }^{95}$. So his particular style of prophesying through direct inspiration also was a secondary development and not an imported oriental practice, as some have supposed ${ }^{96}$. He came to this function through his qualities as healing and purifying deity, as has long been recognized and fully explored ${ }^{97}$. Music provided a third, vital element, and Apollo exercised both his powers of purification and healing through music. The curative magic chant accounts for his office as Musagetes ${ }^{98}$, linked him with poetry 99 and ultimately explains the lyre as the characteristic attribute of his anodyne classical image 100 . Apollo's primary purificatory function remained conspicuous in Delphic myth, but it became submerged in his subsequent brilliant rise to eminence as the most representative god of classical Greek values. He owed his ascendancy amongst other reasons to contemporary social circumstances. In the age of colonial expansion the oracle mediated between gods and men and established Apollo's authority in the countless settlements of the Greek oikists.

That story is well known as an important signal of the Greek renaissance ${ }^{101}$. Inspirational prophecy, too, was a product of the age and clue to contemporary religious thought which was deeply conscious of the need for absolute purity in its striving to communicate directly with the gods ${ }^{102}$. In this respect the idiosyncratic oracular method functionally related to the emergent mystery religions which equally promised divine union to the faithful band of followers. Both had much in common, and the period produced many itinerant purveyors of oracles, who are hard to tell apart from the contemporary charismatic initiator to

95 References in BICS, 25 (1978), p. 2; DIETRICH, Tradition, ch. IV.

96 NiLSSON, GGR, $\mathrm{I}^{3}$, p. 547.

97 Amandry, Mantique, p. 129-130; PARKe, Delphic Oracle, I, p. 8; 190; U. BIANCHI, La Religione Greca, Storia delle Religione, II, Turin, 23 (1976), p. 63; DIETRICH, in BICS, 25 (1978), p. 8-9; L. PRESS, The Worship of Healing Deities, in Archaeologia, 29 (1978), p. 1-15, who discusses the Bronze Age iconography but connects early oracles with tree worship; BURKERT, Homo Necans, p. 130.

98 PINDAR, fr. 116; PLATON, Leg., 653c.

99 2nd century B.C. inscr. from Delphi, $S I G, 699.1$.

100 On the connection of music with healing, see BURKERT, Homo Necans, p. 130.

101 Most recently discussed by I. MALKIN, Religion and Colonization in Ancient Greece, Leiden, 1987, p. 22.

102 On the archaic figure of the initiator, see W. BURKERT, Ancient Mystery Cults, Harvard, 1987, p. 31. 
private mysteries, with similar services on offer, but always through the strict observation of purity. There is no doubt that the Sibylline oracle should also be counted among the symptoms of the same archaic phenomenon. The ecstatic prophetess and her male conterpart Bakis pose some specific problems of their own which can not be addressed here. Their names most likely began as titles but of obscure, non-Greek, etymology, and their oriental origin further obscured their history in the west. In fact the Sibyl's arrival in Greece was not pre-archaic : it can be timed by her close link with epic poetry and myth, although the name does not occur in any authority prior to the 6 th century by which time she had multiplied throughout the Greek world under various guises ${ }^{103}$.

The religious climate, which provided fertile ground for the inspirational oracles and mystery cult, may also have brought Dionysus to the oracle at Delphi, although much of this history lies concealed beneath his later classical function as god of divine frenzy ${ }^{104}$. But a

103 On the Sibyl, see A. Bouché-Leclercq, Histoire de la Divination dans l'Antiquité, repr. Paris, 1963, II, p. 135-185; H. C. O. LaANCHESTER, Sibylline Oracles, in J. HASTINGS, Enc. of. Rel. and Ethics, XI (1920), p. 496-500; RZACH, Sibyllen; Sibyllinische Orakel, in RE, II, A 2 (1923), c. 2073-2183; G. RADKE, Sibyllen, in Kleine Pauly, V (1979), p. 158-161 (with ancient sources); FlaCELIERE, $G r$. Or., p. 27; NILSSON, $G G R, \mathrm{I}^{3}$, p. 174; cf. his review of J.H. Oliver, The Athenian Expounders of the Sacred and Ancestral Law, Baltimore, 1950, in AelPh, 71 (1950), p. 420-425; FonTENRose, Delph. Or., p. 159-160; A. Momigliano, Sibylline Oracles, in The Encyclopedia of Religion (M. ElIADE ed.), XIII, New York, 1987, p. 305-308.

104 He preceded Apollo at the oracle, according to one tradition recorded by the schol. on PIND., Pyth., p. 2. 7, 13 (Drachmann). In fact, Dionysus was secondary to Apollo at Delphi, in his Thracian oracle (HER., 7, 11,2), and at the oracle in Phocia, Ampikleia (PAUS., X, 33, 11), cf. J. Defradas, Les themes de la propagande delphique, Paris, 1954, p. 117. Dionysus' involvement in the myth of the seer Melampus is manifestly late (on Melampus' relationship with Apollo and Zeus in Homer, see VERMEULE, Götterkult, p. 118), tracing back to the Melampodeia epic in which Dionysus replaced Hera as the divine agent inflicting madness on Proteus' daughters from which they were healed by Melampus (First told by Hesiod, Cat., M.P. NiLsson, The Mycenaean Origin of Greek Mythology, Berkeley, 1932, p. 62. On the Melampodeia, see Ingrid LöfFLER, Die Melampodie, 1963, p. 59; M.L. WEST's ed. of Hesiod, Theogony, Oxford, 1966, p. 16). The tradition had become firmly established by the 5 th century B.C. because, according to HERodotus (II, 49), Melampus was the first to introduce the name and rites of Dionysus into Greece. The version of Dionysus' death at the hands of frenzied Maenads also belonged to the 5th century and is first attested in AESCH., Bassarae (fr. 82 Mette; cf. M.L. WEST, in BICS, 30 [1983], p. 64-67; F. GRAF, Orpheus a Poet among Men, in Interpr. of Greek Mythology [J. BREMMER ed.], London, 1987, p. 85). 
clearer view of the intimate relationship between inspirational poetry, prophecy, and the mystery movement is to be had from Orphic myth. As author of theological texts for Dionysus' mysteries and as initiator himself to his own rites, Orpheus played a part in an archaic tradition which accounted for his presence in the Argonaut saga. There perhaps as leader or member of a band of initiates, but certainly as magical singer and dispenser of oracles, Orpheus linked up with Apollo no later than the 7th century B.C. ${ }^{105}$

The will to possess or be possessed by the god furnished the driving force for all the archaic movements, for inspirational mantic as much as for mystery cults. It is a curious phenomenon of Greek religion, which constantly looked back to the past, that both were felt to be rooted in the prehistoric practice of renewal with all its ritual paraphernalia. The telestic Dionysus, of course, had been Divine Child and god of nature from of old. Demeter's earlier function, too, in the realm of chthonic religion never quite disappeared from her mysteries. Apollo's link with vegetation cult was rather less obvious, however : it was forced and puzzling, and yet it evidently provided the common denominator for him and Dionysus at the Delphic oracle.

The outward signs of this strange penchant for the remote past in religion can be read from the tenacious continuity of ancient tradition throughout Greek history. It is of considerable interest, then, that the most important Greek mysteries at Eleusis employed the identical props of ancient chthonic rituals of renewal, although, like the sanctuary of Delphi, the archaeological remains fail to provide satisfactory evidence of an underground chamber or katabasion in the area of the Telesterion 106. And yet at Eleusis, too, the cave remained central to the tradition of the mysteries. Peisistratus in fact reemphasized its importance by building a temple inside the cavern of the Eleusinian

105 The tradition of the oracular head of Orpheus was well established by the 5th century in art and literature, EUR., Alc., p. 966-972. The conflict with Dionysus, which led to Orpheus' death by the Maenads (see previous note) is explained in myth through his function as seer who introduced the worship of Apollo, e.g. S. SPENCER, Mysticism in World Religion, London, 1966, p. 126. But Orpheus was no professional mantis in the Argonautica, his connection with Apollo was as singer, source of magic and healing oracles, according to GRAF, Orpheus, p. 92-95, 99 and suggested, of course, by the chorus of the Alcestis.

G.E. MYLONAS, Eleusis and the Eleusinian Mysteries, Princeton, third print. 1974, p. 268, 270, 311-312, 314; my review of FonTENRose, Delph. Oracle, in $A J P h, 101$ (1980), p. 239-240. On the important tradition of the cave in the mysteries see also BURKERT, Anc. Myst. Cults., p. 95. 
Plutonion 107. Apollo Hylates' oracular cave at Paphos in Cyprus lies next to the route of Aphrodite's mysteries. It must be the most remarkable survival of the link between chthonic cavern, mysteries and oracle ${ }^{108}$.

Common origins do not lead to the same destiny, least of all in religion. In the case of Delphi, historical circumstance, good fortune and political astuteness of the resident priesthood combined to bring world-wide influence to the oracle ensuring Apollo's rise to the status of most luminous figure in the Olympian pantheon. «deus ... non Cassandra loquitur», as Cicero put it ${ }^{109}$, that is, the god spoke directly to the enquirer not through his medium. The special relationship between god and man created a famous public institution at Delphi as well as a model for the civilized world, while mystery religion essentially remained a private form of worship, a self-indulgent escape from the hardships of the real world ${ }^{110}$. Both began and determined their future in the archaic age of Greece.

Bernard C. DIETRICH

Department of Classics

Hugh Owen Building

The University College of Wales

GB-ABERYsTwYTH Dyfed SY233DY

107 The literary tradition is discussed in the light of the archaological evidence by MYLONAS, Eleusis, 268; p. 146-149 (Ploutonion). For the link between the mysteries and the chthonic rites of renewal see B.C. DIETRICH, The Religious Prehistory of Demeter's Eleusinian Mysteries, in La Soteriologia dei Culti Orientali nell' Impero Romano (U. BIANCHI-M.-J. VERMASEREN eds), Leiden, 1982, p. 445-471.

108 Hellenistic, DIETRICH, Traditions, p. 175, with ref.

109 CIC., Div., I, 66.

110 Cf. BURKERT, Anc. Mystery Cults, p. 114. 